\title{
Examining the Influence of Age and Gender on Entrepreneurship in VietnamI
}

\author{
Quang Hung DO', The Tuan TRAN ${ }^{2}$
}

Received: July 18, 2020 Revised: August 23, 2020 Accepted: September 03, 2020

\begin{abstract}
This objective of this study is to examine the influence of age and gender on entrepreneurship in Vietnam's context. Although various studies have been conducted to examine age and gender differences in the entrepreneurial process, the results reveal inconsistencies. Moreover, the relationship between different factors and their role in explaining age and gender differences in the entrepreneurship activities still has no clear answer. Our analyses were based on data collected for the 2017 Global Entrepreneurship Monitors (GEM) from individuals located in Vietnam with a sample of 2,118. Our findings show that female entrepreneurs had less household income and were likely to have more fear of failure in starting a business. Entrepreneurs tend to be older and young entrepreneurs have better education. The study also indicated that male entrepreneurs were likely to have more perception of the ease to start a business. Moreover, the number of male respondents who are currently entrepreneurs is higher and they are older. The contribution of this study is twofold. First, it provides empirical evidence on the age and gender differences in entrepreneurship. Second, it contributes to the understanding of the entrepreneurship environment in Vietnam, one of the most dynamic emerging countries in the East Asian region.
\end{abstract}

Keywords: Age, Gender, Influence, Entrepreneurship, Vietnam

JEL Classification Code: L2, J16, O50

\section{Introduction}

Entrepreneurship is an innovative act of gathering all existing resources with the intention to create new wealth (Lee \& Kim, 2019). Entrepreneurship can be considered as an act of being an entrepreneur, or "the owner or manager of a business enterprise who, by risk and initiative, attempts to make profits". The development of entrepreneurship has long been considered as a driving force of a country's economy. Age and several other demographic variables such as gender, household income and level of education also have been identified as factors that may play a critical role in entrepreneurship. Gender differences can be classified into

${ }^{1}$ First Author. Faculty of Information Technology, University of Transport Technology, Hanoi, Vietnam. Email: hungdq@utt.edu.vn ${ }^{2}$ Corresponding Author. Faculty of Transport Economics, University of Transport Technology, Hanoi, Vietnam [Postal Address: 54 Street Trieu Khuc, Thanh Xuan Nam, Thanh Xuan, Hanoi, 100000, Vietnam] Email: tuantt83@utt.edu.vn

(c) Copyright: The Author(s)

This is an Open Access article distributed under the terms of the Creative Commons Attribution Non-Commercial License (https://creativecommons.org/licenses/by-nc/4.0/) which permits unrestricted non-commercial use, distribution, and reproduction in any medium, provided the original work is properly cited. biological and social concepts. There are gender differences in the brain such as intelligence, spatial and temporal abilities. Moreover, different ways of behaving between the genders can affect each individuals' ability and their likability evaluation (Kim \& Yang, 2020). It was found that gender has an influence on entrepreneurial intentions (Brush et al., 2004; Gupta et al., 2009). Pines et al. (2012) confirmed that men are more entrepreneurial than women. According to GEM Reports on Women and Entrepreneurship, the rates of entrepreneurship in over 40 countries were examined and it showed that in all these countries the rates of women's entrepreneurship were lower than men's (Allen et al., 2007; Tsyganova \& Shirokova, 2010). Based on above-mentioned studies, it can be concluded that gender differences are significantly and systematically observed, and they vary across countries in terms of GDP and region.

Regarding the age differences, the age as a component of the individuals' human capital is considered to be one of important factors of entrepreneurial activity by various studies on entrepreneurship (Parker, 2004). There are different views on the effect of age on individual choice of self-employment as a labor market status. The rationale of the positive impact of age on self-employment is based on the opinion that the quantity of the financial and human 
capital that one possesses and that are necessary for starting and conducting the business increases with age (Arum \& Müller, 2009; Johansson, 2000).

This study focuses on gender and age differences in entrepreneurial activity in the Vietnamese context. The study also seeks to help close a research gap regarding the relationship between age and gender on starting a new business. We draw our analyses on a sample of the general adult population from Vietnam based on the Global Entrepreneurship Monitor. The paper is organized as follows: Section 2 reviews the theory and previous research on gender and age as factors of entrepreneurship. Section 3 is devoted to research methodology. The results are presented in Section 4. Finally, Section 5 provides discussion and conclusions.

\section{Literature Review}

\subsection{Gender as a Factor of Entrepreneurship}

The way a person thinks has a significant impact on the propensity to engage in entrepreneurial activities (Kobeissi, 2010). Thinking "entrepreneurially" leads to the intention to start a business and ultimately to the decision to act on that intention. The propensity to think entrepreneurially and the potential for pursuing entrepreneurial activities in a given country are however conditioned by cultural factors which shape and support entrepreneurial values and motivate new venture formations (Mueller et al. 2001). In many cultures, prevailing gender stereotypes characterize certain jobs or occupational roles as more appropriate for men and others as more appropriate for women. When making their decisions to pursue business growth, a study found that women are more likely than men to consider the opinion of their spouses.

It was documented that there are significant differences in risk aversion between male and female entrepreneurs although they exhibited similar traits (Narayanasamy et al., 2011). Based on Wagner and Sternberg (2004) findings, it was indicated that women have a greater fear of failure than men. Women are less likely to take risks than men. The main challenges facing women were both personal and business related. There was also conflict between the roles traditionally assigned to Asian women and the need to succeed in the marketplace (Dhaliwal \& Kangis, 2006). Women perceived much lower financial risk than men, which indirectly affected the success they attained (Kim \& Hyun, 2011)value-oriented price, promotion, and after-sales service. Women have a variety of economic opportunities for self-realization in entrepreneurial activity. It was concluded that there is a low level of gender discrimination when considering social institutions. The results of the Global Monitoring of Entrepreneurship confirm that in Kazakhstan there is a new wave of female entrepreneurship, where women are engaged in entrepreneurial activities by virtue of realizing their potential and finding new opportunities (Satpayeva et al., 2020).

\subsection{Age as a Factor of Entrepreneurship}

Differences in the interpretation of the impact of age on self-employment can be explained by separating the two aspects of this relationship (Stefanović \& Stošić, 2012). A distinction between the willingness (desire) and the possibility to be an entrepreneur should be made. An individual who is ready, i.e., motivated for this option will become an entrepreneur in a favorable environment. If one or both of the conditions is not met, either willingness or possibility, an individual will not choose the self-employment option. If age is taken as a determinant of the size of the financial, human and social capital that an individual has, it can be assumed that the possibility to become an entrepreneur will increase with age (Praag \& Ophem, 1995). On the other hand, the willingness of individuals to be self-employed decreases with age. Therefore, while the seniors have more possibility to become self-employed, young people have a greater desire to be so. It was found that more people are willing to be self-employed relative to those who are able to become so. If an individual who wants to be an entrepreneur had the opportunity to be one, the number of new companies would be up to seven times higher. Thus, the barriers for selfemployment are more on the side of possibilities, and less on the willingness to be self-employed. Taking into account the arguments for and against the positive impact of age on self-employment, it is argued that there is an age limit, after which the willingness of individuals to start their own entrepreneurial ventures decreases, and that is most likely that the individuals who are in the middle of their careers will become self-employed. The non-linear dynamics of the self-employment rates in relation to the age should be analyzed in the context of certain studies that found that the probability to be self-employed increases with age, but only to a certain limit, after which it decreases, or stabilizes (Bates, 1995; Blanchflower, 2000).

\section{Research Methodology}

\subsection{Data Collection}

Our analysis is based on a representative sample of the adult population from Vietnam (=2089). Our study utilized 2017 GEM data. The survey was conducted to gather information about the entrepreneurship characteristics in different stages, from intending to start, to just starting, to running a new or established enterprise and even to terminate a business. Based on Adult Population Survey (APS), 2017 GEM data has provided information on components of the entrepreneurship ecosystem using a Likert scale. 


\subsection{Dependent and Predictor Variable}

For gender difference analysis, the dependent variable was gender $(0=$ male, $1=$ female $)$. In order to test our hypotheses, other variables were included into the model. Individual control variables are age of participants (in years), and household income as measured by three different categories. Through extensive literature review, we included "fear of failure" as a control variable by asking the following question: "Would fear of failure prevent you from starting a business?" The 'availability of opportunities' in the environment was also included into the model and identified by the following question: "In the next six months, will there be good opportunities for starting a business in the area where you live?". These variables are also binary variable $(1=$ Yes, $0=$ No). The "having knowledge, skills and experience required to start a new business" was identified by the following question "Do you have the knowledge, skill and experience required to start a new business?" The "personally know an entrepreneur" was obtained by "Do you know someone personally who started a business in the past 2 years?" The perception of the "ease to start a business" was identified by "It is easy to start a business?" For age difference analysis, the dependent variable was age and the predictor variables were similar to gender difference analysis.

The variables and their descriptions are summarized in Table 1.

\subsection{Data Analysis}

The proposed regression model for gender difference analysis is logistic regression because of the followings: (i) all the independent variables are dichotomous or categorical and (ii) the dependent variable is dichotomous. Logistic regression method is used to describe data and to understand the relationship between one dependent binary variable and one or more nominal, ordinal, interval or ratio-level independent variables. In many cases, that dependent binary variable (outcome event) can be easily categorized into classes of having occurred, or not having occurred, i.e., the occurrence of a stroke, or of going bankrupt, are relatively easily discerned and coded as either having happened, or not having happened. Once this categorization has been obtained, the independent variables (predictors of that outcome) can be studied (De Almeida Fleck et al., 2005; Reed \& Wu, 2013). A concern in developing of a logistic regression model is which variables are selected to analyze as potential predictors of the outcome.

The linear regression analysis is used for age difference analysis. It is to model the relationship between a dependent variable and one or more explanatory variables (or independent variables).

\section{Results}

The SPSS statistical software was used to analyze the data and the results are presented in Tables 2-5. Based on Chi-square test analysis in Table 2, with respect to the following variables - education attainment, opportunity, having knowledge, skills and experience, and personally know an entrepreneur - no appreciable differences were found between male and female respondents.

As shown in Table 3, regarding the two variables, including fear of failure and perception of the ease to start a business, no difference was found between age groups.

Table 1: Individual-level variables

\begin{tabular}{|c|c|}
\hline Variable & Description \\
\hline Currently being an entrepreneur & Dummy = 1 if the respondent is an entrepreneur \\
\hline Fear of failure & $\begin{array}{l}\text { Dummy }=1 \text { if respondents stated that fear of failure who would prevent them } \\
\text { from starting a business }\end{array}$ \\
\hline Educational attainment & $\begin{array}{l}1=\text { No secondary degree; } 2 \text { = Secondary degree; } 3=\text { Post secondary; } 4= \\
\text { Graduate experience }\end{array}$ \\
\hline Household income & Categorical variable: 1 = Lowest; 2 = Middle; 3 = Upper \\
\hline Opportunity & $\begin{array}{l}\text { Dummy = } 1 \text { if the respondents stated that there will be good opportunities for } \\
\text { starting a business in the area where they live in the next six months }\end{array}$ \\
\hline $\begin{array}{l}\text { Having knowlegde, skills and experience } \\
\text { required to start a new business }\end{array}$ & $\begin{array}{l}\text { Dummy }=1 \text { if respondents had the knowledge, skill and experience required to } \\
\text { start a new business }\end{array}$ \\
\hline Personally know an entrepreneur & $\begin{array}{l}\text { Dummy = } 1 \text { if respondents knew someone personally who started a business } \\
\text { in the past } 2 \text { years. }\end{array}$ \\
\hline Perception of the ease to start a business & Dummy $=1$ if respondents stated that it is easy to start a business \\
\hline Age & Age of respondents in years \\
\hline Gender & Dummy $=1$ if the respondent is male \\
\hline
\end{tabular}


Table 2: Chi-square tests and descriptive statistics based on gender

\begin{tabular}{|c|c|c|c|c|c|}
\hline & \multicolumn{2}{|c|}{ Male } & \multicolumn{2}{|c|}{ Female } \\
\hline & & & $\%$ & & $\%$ \\
\hline \multirow[t]{4}{*}{ Currently being an entrepreneur* } & Refused & 0 & $0.0 \%$ & 0 & $0.0 \%$ \\
\hline & Don't Know & 0 & $0.0 \%$ & 0 & $0.0 \%$ \\
\hline & Yes & 242 & $23.4 \%$ & 306 & $28.2 \%$ \\
\hline & No & 790 & $76.6 \%$ & 780 & $71.8 \%$ \\
\hline \multirow[t]{4}{*}{ Fear of failure* } & Refused & 0 & $0.0 \%$ & 0 & $0.0 \%$ \\
\hline & Don’t Know & 4 & $0.4 \%$ & 14 & $1.3 \%$ \\
\hline & Yes & 553 & $53.6 \%$ & 614 & $56.5 \%$ \\
\hline & No & 475 & $46.0 \%$ & 458 & $42.2 \%$ \\
\hline \multirow[t]{8}{*}{ Education attainment } & Pre-primary (Kindergarten) & 0 & $0.0 \%$ & 0 & $0.0 \%$ \\
\hline & Primary education & 82 & $8.0 \%$ & 95 & $8.8 \%$ \\
\hline & Lower secondary & 160 & $15.5 \%$ & 172 & $15.9 \%$ \\
\hline & Upper secondary & 262 & $25.5 \%$ & 271 & $25.0 \%$ \\
\hline & College & 190 & $18.5 \%$ & 169 & $15.6 \%$ \\
\hline & University & 313 & $30.4 \%$ & 351 & $32.4 \%$ \\
\hline & Masters & 21 & $2.0 \%$ & 24 & $2.2 \%$ \\
\hline & Doctorate & 1 & $0.1 \%$ & 0 & $0.0 \%$ \\
\hline \multirow[t]{6}{*}{ Household income $^{* * *}$} & 0 to $25.000 .000 \mathrm{VND}$ & 20 & $2.0 \%$ & 39 & $3.6 \%$ \\
\hline & 25.000 .000 to 50.000 .000 VND & 78 & $7.7 \%$ & 93 & $8.6 \%$ \\
\hline & 50.000 .000 to 100.000 .000 VND & 186 & $18.3 \%$ & 207 & $19.2 \%$ \\
\hline & 100.000 .000 to 150.000 .000 VND & 236 & $23.2 \%$ & 264 & $24.5 \%$ \\
\hline & 150.000 .000 to $200.000 .000 \mathrm{VND}$ & 234 & $23.0 \%$ & 242 & $22.5 \%$ \\
\hline & More than 200.000 .000 VND & 265 & $26.0 \%$ & 231 & $21.5 \%$ \\
\hline \multirow[t]{4}{*}{ Opportunity } & Refused & 0 & $0.0 \%$ & 0 & $0.0 \%$ \\
\hline & Don't Know & 27 & $2.6 \%$ & 26 & $2.4 \%$ \\
\hline & Yes & 465 & $45.1 \%$ & 508 & $46.8 \%$ \\
\hline & No & 540 & $52.3 \%$ & 552 & $50.8 \%$ \\
\hline \multirow{4}{*}{$\begin{array}{l}\text { Having knowlegde, skills and } \\
\text { experience }\end{array}$} & Refused & 1 & $0.1 \%$ & 0 & $0.0 \%$ \\
\hline & Don't Know & 7 & $0.7 \%$ & 8 & $0.7 \%$ \\
\hline & Yes & 537 & $52.0 \%$ & 578 & $53.2 \%$ \\
\hline & No & 487 & $47.2 \%$ & 500 & $46.0 \%$ \\
\hline \multirow[t]{4}{*}{ Personally know an entrepreneur } & Refused & 0 & $0.0 \%$ & 0 & $0.0 \%$ \\
\hline & Don't Know & 11 & $1.1 \%$ & 9 & $0.8 \%$ \\
\hline & Yes & 609 & $59.0 \%$ & 652 & $60.0 \%$ \\
\hline & No & 412 & $39.9 \%$ & 425 & $39.1 \%$ \\
\hline \multirow{4}{*}{$\begin{array}{l}\text { Perception of the ease to start a } \\
\text { business }^{* *}\end{array}$} & Refused & 0 & $0.0 \%$ & 0 & $0.0 \%$ \\
\hline & Don't Know & 13 & $1.3 \%$ & 22 & $2.0 \%$ \\
\hline & Yes & 455 & $44.1 \%$ & 524 & $48.3 \%$ \\
\hline & No & 564 & $54.7 \%$ & 540 & $49.7 \%$ \\
\hline \multirow[t]{7}{*}{$\mathrm{Age}^{\star \star \star}$} & $0-17$ & 0 & $0.0 \%$ & 0 & $0.0 \%$ \\
\hline & $18-24$ & 231 & $22.4 \%$ & 278 & $25.6 \%$ \\
\hline & $25-34$ & 268 & $26.0 \%$ & 278 & $25.6 \%$ \\
\hline & $35-44$ & 210 & $20.3 \%$ & 246 & $22.7 \%$ \\
\hline & \begin{tabular}{|l|}
$45-54$ \\
\end{tabular} & 205 & $19.9 \%$ & 188 & $17.3 \%$ \\
\hline & $55-64$ & 118 & $11.4 \%$ & 96 & $8.8 \%$ \\
\hline & $65-129$ & 0 & $0.0 \%$ & 0 & $0.0 \%$ \\
\hline
\end{tabular}

${ }^{*}: p<0.10 ;{ }^{* *}: p<0.05 ;{ }^{* *}: p<0.01 ;{ }^{* * *}: p<0.001$ (Chi-square test) 
Table 3: Chi-square tests and descriptive statistics based on age group

\begin{tabular}{|c|c|c|c|c|c|c|c|c|c|c|c|}
\hline \multirow{2}{*}{\multicolumn{2}{|c|}{ Age }} & \multicolumn{2}{|c|}{$18-24$} & \multicolumn{2}{|c|}{$25-34$} & \multicolumn{2}{|c|}{$35-44$} & \multicolumn{2}{|c|}{$45-54$} & \multicolumn{2}{|c|}{$55-64$} \\
\hline & & & $\%$ & & $\%$ & & $\%$ & & $\%$ & & $\%$ \\
\hline \multirow{4}{*}{$\begin{array}{l}\text { Currently being an } \\
\text { entrepreneur }\end{array}$} & Refused & 0 & $0.0 \%$ & 0 & $0.0 \%$ & 0 & $0.0 \%$ & 0 & $0.0 \%$ & 0 & $0.0 \%$ \\
\hline & Don't Know & 0 & $0.0 \%$ & 0 & $0.0 \%$ & 0 & $0.0 \%$ & 0 & $0.0 \%$ & 0 & $0.0 \%$ \\
\hline & Yes & 135 & $26.5 \%$ & 178 & $32.6 \%$ & 110 & $24.1 \%$ & 92 & $23.4 \%$ & 33 & $15.4 \%$ \\
\hline & No & 374 & $73.5 \%$ & 368 & $67.4 \%$ & 346 & $75.9 \%$ & 301 & $76.6 \%$ & 181 & $84.6 \%$ \\
\hline \multirow[t]{4}{*}{ Fear of failure } & Refused & 0 & $0.0 \%$ & 0 & $0.0 \%$ & 0 & $0.0 \%$ & 0 & $0.0 \%$ & 0 & $0.0 \%$ \\
\hline & Don't Know & 4 & $0.8 \%$ & 4 & $0.7 \%$ & 4 & $0.9 \%$ & 3 & $0.8 \%$ & 3 & $1.4 \%$ \\
\hline & Yes & 308 & $60.5 \%$ & 304 & $55.7 \%$ & 224 & $49.1 \%$ & 222 & $56.5 \%$ & 109 & $50.9 \%$ \\
\hline & No & 197 & $38.7 \%$ & 238 & $43.6 \%$ & 228 & $50.0 \%$ & 168 & $42.7 \%$ & 102 & $47.7 \%$ \\
\hline \multirow[t]{8}{*}{$\begin{array}{l}\text { Education } \\
\text { attainment }\end{array}$} & $\begin{array}{l}\text { Pre-primary } \\
\text { (Kindergarten) }\end{array}$ & 0 & $0.0 \%$ & 0 & $0.0 \%$ & 0 & $0.0 \%$ & 0 & $0.0 \%$ & 0 & $0.0 \%$ \\
\hline & Primary education & 5 & $1.0 \%$ & 14 & $2.6 \%$ & 58 & $12.7 \%$ & 50 & $12.8 \%$ & 50 & $23.6 \%$ \\
\hline & Lower secondary & 33 & $6.5 \%$ & 71 & $13.0 \%$ & 104 & $22.9 \%$ & 86 & $22.1 \%$ & 38 & $17.9 \%$ \\
\hline & Upper secondary & 106 & $20.9 \%$ & 136 & $24.9 \%$ & 110 & $24.2 \%$ & 119 & $30.5 \%$ & 62 & $29.2 \%$ \\
\hline & College & 87 & $17.1 \%$ & 107 & $19.6 \%$ & 69 & $15.2 \%$ & 63 & $16.2 \%$ & 33 & $15.6 \%$ \\
\hline & University & 271 & $53.3 \%$ & 195 & $35.7 \%$ & 103 & $22.6 \%$ & 66 & $16.9 \%$ & 29 & $13.7 \%$ \\
\hline & Masters & 6 & $1.2 \%$ & 23 & $4.2 \%$ & 11 & $2.4 \%$ & 5 & $1.3 \%$ & 0 & $0.0 \%$ \\
\hline & Doctorate & 0 & $0.0 \%$ & 0 & $0.0 \%$ & 0 & $0.0 \%$ & 1 & $0.3 \%$ & 0 & $0.0 \%$ \\
\hline \multirow[t]{6}{*}{ Household income ${ }^{* \star * *}$} & $\begin{array}{l}0 \text { to } 25.000 .000 \\
\text { VND }\end{array}$ & 15 & $3.0 \%$ & 12 & $2.2 \%$ & 6 & $1.3 \%$ & 15 & $3.9 \%$ & 11 & $5.3 \%$ \\
\hline & $\begin{array}{l}25.000 .000 \text { to } \\
50.000 .000 \text { VND }\end{array}$ & 31 & $6.2 \%$ & 31 & $5.7 \%$ & 46 & $10.1 \%$ & 39 & $10.0 \%$ & 24 & $11.5 \%$ \\
\hline & $\begin{array}{l}50.000 .000 \text { to } \\
100.000 .000 \text { VND }\end{array}$ & 75 & $15.0 \%$ & 120 & $22.2 \%$ & 92 & $20.2 \%$ & 65 & $16.7 \%$ & 41 & $19.6 \%$ \\
\hline & $\begin{array}{l}100.000 .000 \text { to } \\
150.000 .000 \text { VND }\end{array}$ & 127 & $25.4 \%$ & 114 & $21.1 \%$ & 111 & $24.3 \%$ & 95 & $24.4 \%$ & 53 & $25.4 \%$ \\
\hline & $\begin{array}{l}\text { 150.000.000 to } \\
200.000 .000 \text { VND }\end{array}$ & 122 & $24.4 \%$ & 129 & $23.8 \%$ & 104 & $22.8 \%$ & 82 & $21.1 \%$ & 39 & $18.7 \%$ \\
\hline & $\begin{array}{l}\text { More than } \\
200.000 .000 \text { VND }\end{array}$ & 130 & $26.0 \%$ & 135 & $25.0 \%$ & 97 & $21.3 \%$ & 93 & $23.9 \%$ & 41 & $19.6 \%$ \\
\hline \multirow[t]{4}{*}{ Opportunity* } & Refused & 0 & $0.0 \%$ & 0 & $0.0 \%$ & 0 & $0.0 \%$ & 0 & $0.0 \%$ & 0 & $0.0 \%$ \\
\hline & Don't Know & 9 & $1.8 \%$ & 7 & $1.3 \%$ & 15 & $3.3 \%$ & 13 & $3.3 \%$ & 9 & $4.2 \%$ \\
\hline & Yes & 272 & $53.4 \%$ & 246 & $45.1 \%$ & 217 & $47.6 \%$ & 152 & $38.7 \%$ & 86 & $40.2 \%$ \\
\hline & No & 228 & $44.8 \%$ & 293 & $53.7 \%$ & 224 & $49.1 \%$ & 228 & $58.0 \%$ & 119 & $55.6 \%$ \\
\hline \multirow{4}{*}{$\begin{array}{l}\text { Having knowlegde, } \\
\text { skills and } \\
\text { experience }{ }^{\star * *}\end{array}$} & Refused & 1 & $0.2 \%$ & 0 & $0.0 \%$ & 0 & $0.0 \%$ & 0 & $0.0 \%$ & 0 & $0.0 \%$ \\
\hline & Don't Know & 5 & $1.0 \%$ & 6 & $1.1 \%$ & 1 & $0.2 \%$ & 3 & $0.8 \%$ & 0 & $0.0 \%$ \\
\hline & Yes & 231 & $45.4 \%$ & 298 & $54.6 \%$ & 272 & $59.6 \%$ & 212 & $53.9 \%$ & 102 & $47.7 \%$ \\
\hline & No & 272 & $53.4 \%$ & 242 & $44.3 \%$ & 183 & $40.1 \%$ & 178 & $45.3 \%$ & 112 & $52.3 \%$ \\
\hline \multirow{4}{*}{$\begin{array}{l}\text { Personally know an } \\
\text { entrepreneur }^{* * * *}\end{array}$} & Refused & 0 & $0.0 \%$ & 0 & $0.0 \%$ & 0 & $0.0 \%$ & 0 & $0.0 \%$ & 0 & $0.0 \%$ \\
\hline & Don't Know & 2 & $0.4 \%$ & 0 & $0.0 \%$ & 8 & $1.8 \%$ & 1 & $0.3 \%$ & 9 & $4.2 \%$ \\
\hline & Yes & 333 & $65.4 \%$ & 361 & $66.1 \%$ & 264 & $57.9 \%$ & 203 & $51.7 \%$ & 100 & $46.7 \%$ \\
\hline & No & 174 & $34.2 \%$ & 185 & $33.9 \%$ & 184 & $40.4 \%$ & 189 & $48.1 \%$ & 105 & $49.1 \%$ \\
\hline \multirow{4}{*}{$\begin{array}{l}\text { Perception of the ease } \\
\text { to start a business }\end{array}$} & Refused & 0 & $0.0 \%$ & 0 & $0.0 \%$ & 0 & $0.0 \%$ & 0 & $0.0 \%$ & 0 & $0.0 \%$ \\
\hline & Don't Know & 4 & $0.8 \%$ & 7 & $1.3 \%$ & 12 & $2.6 \%$ & 9 & $2.3 \%$ & 3 & $1.4 \%$ \\
\hline & Yes & 259 & $50.9 \%$ & 233 & $42.7 \%$ & 209 & $45.8 \%$ & 170 & $43.3 \%$ & 108 & $50.5 \%$ \\
\hline & No & 246 & $48.3 \%$ & 306 & $56.0 \%$ & 235 & $51.5 \%$ & 214 & $54.5 \%$ & 103 & $48.1 \%$ \\
\hline \multirow[t]{4}{*}{ Gender** } & Refused & 0 & $0.0 \%$ & 0 & $0.0 \%$ & 0 & $0.0 \%$ & 0 & $0.0 \%$ & 0 & $0.0 \%$ \\
\hline & Don't Know & 0 & $0.0 \%$ & 0 & $0.0 \%$ & 0 & $0.0 \%$ & 0 & $0.0 \%$ & 0 & $0.0 \%$ \\
\hline & Male & 231 & $45.4 \%$ & 268 & $49.1 \%$ & 210 & $46.1 \%$ & 205 & $52.2 \%$ & 118 & $55.1 \%$ \\
\hline & Female & 278 & $54.6 \%$ & 278 & $50.9 \%$ & 246 & $53.9 \%$ & 188 & $47.8 \%$ & 96 & $44.9 \%$ \\
\hline
\end{tabular}

${ }^{*}: p<0.10 ;{ }^{* *}: p<0.05 ;{ }^{* *}: p<0.01 ;{ }^{* * * *}: p<0.001$ (Chi-square test) 
Table 4: Binary Regression Analysis using Gender as Dependent Variable ${ }^{\text {a }}$

\begin{tabular}{|l|c|}
\hline Variable & Coefficient \\
\hline Currently being an entrepreneur & $-.226(.798)^{*}$ \\
\hline Fear of failure & $-.219(.803)^{\star *}$ \\
\hline Education attainment & $-.005(.995)$ \\
\hline Household income & $-.105(.900)^{\star *}$ \\
\hline Opportunity & $-.029(.971)$ \\
\hline $\begin{array}{l}\text { Having knowlegde, skills and experience } \\
\text { required to start a new business }\end{array}$ & $-.019(.981)$ \\
\hline Personally know an entrepreneur & $-.013(.987)$ \\
\hline Perception of the ease to start a business & $-.177(.838)^{*}$ \\
\hline Age & $-.009(.991)^{* *}$ \\
\hline Constant & 1.878 \\
& $(6.543)^{\star * *}$ \\
\hline
\end{tabular}

${ }^{* * *} p<.001 ;{ }^{* *} p<.01 ;{ }^{*} p<.05$ one-sided tests for hypothesized variables, two sided tests for control variables

Notes: a Regression coefficients and corresponding 'odds ratios' (in parentheses) are presented. The odds ratio is to approximate how much more likely (or unlikely) it is for the outcome (being engaged in start-up activity) to be true; ' 'Lowest income' is used as base case in the binary regression analyses.

Table 5: Linear Regression Analysis using Age as Dependent Variable

\begin{tabular}{|l|c|}
\hline Variable & Coefficient \\
\hline Currently being an entrepreneur & $2.952^{*}$ \\
\hline Fear of failure & 1.011 \\
\hline Education attainment & $-3.265^{*}$ \\
\hline Household income & 400 \\
\hline Opportunity & -.029 \\
\hline $\begin{array}{l}\text { Having knowlegde, skills and experience } \\
\text { required to start a new business }\end{array}$ & -.172 \\
\hline Personally know an entrepreneur & 1.002 \\
\hline Perception of the ease to start a business & .812 \\
\hline Constant & $35.698^{*}$ \\
\hline
\end{tabular}

Notes: ${ }^{*} p<.05$, Regression coefficients are presented.

As presented in Table 4, the predictors to be an entrepreneur - fear of failure, household income, perception of the ease to start a business, and age - are significant at the $5 \%$ level. The predictors education attainment, opportunity, having knowledge, skills and experience required to start a new business, and personally know an entrepreneur, are not significant. Therefore, gender was predicted by five variables.
When compared to male, female entrepreneurs had a lower household income and were less likely to have more fear of failure in starting a business. Also, male entrepreneurs were likely to have more perception of the ease to start a business. Moreover, the number of male respondents who are currently entrepreneurs are higher and the age of male entrepreneurs are also higher.

As presented in Table 5, the predictor to be an entrepreneur - education attainment - is significant at the $5 \%$ level. The other predictors are not significant variables. This means that entrepreneurs in Vietnam tend to be older. Moreover, we clearly see that the youngsters have better education. These findings are aligned with previous studies on entrepreneurship in other countries and regions.

\section{Discussion and Conclusions}

This study sought to explain the relationship between age and gender and entrepreneurship in Vietnam. Age and gender are introduced as explanatory variables in most models of choice of entrepreneurship as a work engagement option. Based on the results, our results confirmed that the possibility of self-employment increases with age. Given the characteristics of the business environment in Vietnam, as in most emerging economies, it seems that the limited number of work engagement options for older labor market participants is a key factor of their self-employment. With the aim to create a younger age structure of employees, the management of newly-privatized firms often offers socalled social programs through which older workers leave their companies for certain compensation per year of work. Thus, self-employment often becomes the only employment options for older individuals who become unemployed after the privatization or closure of large public companies. Other than that, the impact of age difference on entrepreneurship is reflected on internal factors and external factors from entrepreneurs. Theoretically, entrepreneurs were expected to have high motivation, resources and experience, and could be influenced by family. These factors can vary with age; they were investigated among entrepreneurs in Vietnam.

The findings showed that women are still much less likely than men to believe they are competent as an entrepreneur. This study also suggests that the gender gap in business ownership remains high in Vietnam. The gap in female entrepreneurship is especially obvious in Vietnam where women are much less likely than men to start a new business. This suggests a need to intensify efforts to boost female business ownership. This study also explored reinforcing factors that impact female entrepreneurship, including women's financial inclusion (household income). In this respect, further research is needed to provide policy-relevant evidence on female entrepreneurship. The development of solutions to reduce the existing gender gap in business 
formation would also require in-depth analysis of business demography, characteristics of women-owned businesses, and determinants of their growth.

In all, the study investigated the influence of age and gender differences on entrepreneurship, especially focused in Vietnam. It is clear from these factors related to entrepreneurship, it is practical issues that are spreading the entrepreneurship spirit in Vietnam. It is helpful to policymakers, educators who want to take full advantage of these characteristics. It is also helpful to individuals who are going to pursue entrepreneurship on how to improve themselves and grasp opportunities at the right time. Additionally, the study findings also offer a comparison of the situations in other countries, giving them some inspirations for locally-based entrepreneurships.

\section{References}

Allen, I. E., Langowitz, N., \& Minniti, M. (2007). Global entrepreneurship monitor. 2006 Report on Women and Entrepreneurship, 3(1), 54-88.

Arum, R., \& Müller, W. (Eds.). (2009). The reemergence of selfemployment: a comparative study of self-employment dynamics and social inequality. Princeton, NJ: Princeton University Press.

Bates, T. (1995). Self-employment entry across industry groups. Journal of Business Venturing, 10(2), 143-156. https://doi. org/10.1016/0883-9026(94)00018-P

Blanchflower, D. G. (2000). Self-employment in OECD countries. Labour Economics, 7(5), 471-505.

Brush, C., Carter, N., Gatewood, E., Greene, P., \& Hart, M. (2004). Clearing the hurdles: Women building high-growth businesses. Upper Saddle River, NJ: FT Press.

Fleck, M. P. D. A., Simon, G., Herrman, H., Bushnell, D., Martin, M., \& Patrick, D. (2005). Major depression and its correlates in primary care settings in six countries: 9-month follow-up study. The British Journal of Psychiatry, 186(1), 41-47.

Dhaliwal, S., \& Kangis, P. (2006). Asians in the UK: gender, generations and enterprise. Equal Opportunities International, 25(2), 92-108.

Gupta, V. K., Turban, D. B., Wasti, S. A., \& Sikdar, A. (2009). The role of gender stereotypes in perceptions of entrepreneurs and intentions to become an entrepreneur. Entrepreneurship Theory and Practice, 33(2), 397-417.

Johansson, E. (2000). Self-employment and liquidity constraints: evidence from Finland. Scandinavian Journal of Economics, 102(1), 123-134.

Kim, J. H., \& Hyun, Y. J. (2011). A model to investigate the influence of marketing-mix efforts and corporate image on brand equity in the IT software sector. Industrial Marketing Management, 40(3), 424-438.

Kim, Y. E., \& Yang, H. C. (2020). The Effects of Perceived Satisfaction Level of High-Involvement Product Choice Attribute of Millennial Generation on Repurchase Intention: Moderating Effect of Gender Difference. Journal of Asian Finance, Economics and Business, 7(1), 131-140. https://doi. org/10.13106/jafeb.2020.vol7.no1.131

Kobeissi, N. (2010). Gender factors and female entrepreneurship: International evidence and policy implications. Journal of International Entrepreneurship, 8(1), 1-35.

Lee, W.-S., \& Kim, B.-Y. (2019). The Effects of Career Orientations on Entrepreneurial Satisfaction and Business Sustainability. Journal of Asian Finance, Economics and Business, 6(4), 235-248. https://doi.org/10.13106/jafeb.2019. vol6.no4.235

Narayanasamy, K., Rasiah, D., \& Jacobs, C. J. (2011). An empirical study of factors influencing gender differences in entrepreneurship. International Business \& Economics Research Journal, 10(10), 17-30.

Parker, S. C. (2004). The economics of self-employment and entrepreneurship. Cambridge, UK: Cambridge University Press.

Pines, A. M., Lerner, M., \& Schwartz, D. (2012). Gender differences among social vs. business entrepreneurs. In: Entrepreneurship: Gender, Geographies and Social Context (pp. 3-14). DOI: $10.5772 / 38179$

Praag, C. M., \& Ophem, H. (1995). Determinants of willingness and opportunity to start as an entrepreneur. Kyklos, 48(4), 513540.

Reed, P., \& Wu, Y. (2013). Logistic regression for risk factor modelling in stuttering research. Journal of Fluency Disorders, 38(2), 88-101.

Satpayeva, Z. T., Kireyeva, A. A., Kenzhegulova, G., \& Yermekbayeva, D. (2020). Gender Equality and Women Business of Framework 5Ms in Kazakhstan: Analysis and Basic Directions. Journal of Asian Finance, Economics and Business, 7(3), 253-263. https://doi.org/10.13106/jafeb.2020. vol7.no3.253

Stefanović, S., \& Stošić, D. (2012). Age and education as determinants of entrepreneurship. Facta Universitatis-Series Economics and Organization, 9(3), 327-339.

Tsyganova, T., \& Shirokova, G. (2010). Gender Differences in Entrepreneurship: Evidence from Gem Data. Organizations and Markets in Emerging Economies, 1(1), 120-141.

Wagner, J., \& Sternberg, R. (2004). Start-up activities, individual characteristics, and the regional milieu: Lessons for entrepreneurship support policies from German micro data. The Annals of Regional Science, 38(2), 219-240. 